\title{
PELATIHAN KOMPOSTING SAMPAH SKALA RUMAH TANGGA DALAM PENGELOLAAN SAMPAH BERBASIS MASYARAKAT DESA KETEGAN TANGGULANGIN SIDOARJO
}

\author{
Oleh: \\ Dini Ermavitalini ${ }^{1}$, Nurul Jadid ${ }^{2}$, Wirdhatul Muslihatin ${ }^{3}$, Triono Bagus Saputro ${ }^{4}$, Maya Shovitri ${ }^{5}$, \\ Endry Nugroho Prasetyo ${ }^{6}$, Noor Nailis Sa'adah ${ }^{7}$, Kristanti Indah Purwani $^{8}$ \\ 1,2,3,4,5,6,7,8 Departemen Biologi Institut Teknologi Sepuluh Nopember Surabaya \\ 1dinierma@bio.its.ac.id
}

\begin{abstract}
Abstrak
Seiring dengan bertambahnya manusia beserta seluruh kegiatan ekonomi yang dilakukan, sampah menjadi cemaran yang secara terus menerus menyisakan permasalahan. Kabupaten Sidoarjo memiliki 18 kecamatan dengan 350 desa dan jumlah penduduk sekitar 2.3 juta jiwa dengan tingkat pertumbuhan ekonomi yang tinggi. Menurut Data Dinas Lingkungan Hidup dan Kebersihan (DLHK) Kabupaten Sidoarjo tahun 2017, melaporkan penduduk kabupaten Sidoarjo membuang limbah rumah tangga sekitar $0.5 \mathrm{~kg}$ setiap harinya. DLHK mengidentifikasi kurangnya Tempat Pengelolaan Sampah Terpadu (TPST) dan Tempat Pembuangan Akhir Sampah (TPAS) untuk menampung dan mengelola sampah dari masyarakat Kabupaten Sidoarjo. Kekurangan jumlah TPST dan TPAS bukan menjadi masalah dalam pengelolaan sampah apabila terlaksana keterlibatan masyarakat secara aktif dalam mengolah sampah rumah tangganya yang dikenal sebagai Pengelolaan Sampah Berbasis Masyarakat (PSBM). Metode abdimas ini adalah kampanye tentang pentingnya peran masyarakat dalam meningkatkan status lingkungan hidup serta pelatihan komposting dengan bahan baku berupa limbah dapur dengan alat sederhana skala rumah tangga yang bertempat di kantor Desa Ketegan Kecamatan Tanggulangin Sidoarjo. Peserta sangat antusias mengikuti pelatihan dan sangat ingin mempraktekkan komposting sampah skala rumah tangga untuk kebutuhan pemupukan tanaman yang ditanam di halaman rumah. Peserta menginginkan adanya monitoring oleh tim pengabdi terhadap hasil komposting yang telah dilakukan masing masing peserta.
\end{abstract}

Kata Kunci: Desa Ketegan Tanggulangin Sidoarjo, kampanye dan pelatihan, komposting skala rumah tangga, pengelolaan sampah berbasis masyarakat, limbah dapur

\begin{abstract}
Along with the increasing number of people and all economic activities carried out, waste becomes a contamination that continues to leave problems. Sidoarjo Regency has 18 sub-districts with 350 villages and a population of around 2.3 million people with a high level of economic growth. According to the 2017 Sidoarjo Regency Environmental and Hygiene Office (DLHK), reported that Sidoarjo district residents dispose of household waste around $0.5 \mathrm{~kg}$ per day. DLHK identifies the lack of Integrated Waste Management Sites (TPST) and Final Waste Disposal Sites (TPAS) to accommodate and manage waste from the Sidoarjo Regency community. The lack of TPST and TPAS is not a problem in waste management if active community involvement is involved in processing household waste known as Community Based Waste Management (PSBM). This abdimas method is a campaign about the importance of the role of the community in improving environmental status and composting training with raw materials in the form of kitchen waste with a simple household-scale tool located in the Ketegan Village office, Tanggulangin Sub-district, Sidoarjo. The participants were very enthusiastic about taking part in the training and were eager to practice household composting on a household scale for the need to fertilize plants planted in the yard. Participants want monitoring by the service team on the composting results that have been carried out by each participant.
\end{abstract}

Keywords: Ketegan Tanggulangin Village Sidoarjo, campaign and training, household scale composting, community based waste management, kitchen waste

\section{PENDAHULUAN}

Sampah adalah sebagian dari sesuatu yang tidak disenangi dan tidak dipakai yang harus dibuang sebagai hasil dari kegiatan manusia. Sampah dapat berupa bahan padatan, cair dan gas yang bisa bersumber dari rumah tangga, pasar, warung, kantor, pabrik, dan jalan (Azwar, 1990). Seiring dengan pertumbuhan dan perkembangan kegiatan ekonomi masyarakat, menyisakan 
berbagai permasalahan yang tidak bisa terelakkan antara lain pengalihfungsian lahan subur menjadi pemukiman dan pusat pusat industri, peningkatan volume sampah dan polusi, pengurangan ketersediaan air bersih dan lain sebagainya. Peningkatan jumlah sampah selain akibat dari aktivitas masyarakat juga disebabkan karena sistem pengelolaan sampah yang kurang efektif, kebiasaan penduduk yang tidak bersahabat dengan lingkungan hidup, pengetahuan masyarakat yang kurang mengenai dampak sampah, keadaan geografi serta tingkat sosial ekonomi (Depkes RI, 1987).

Kabupaten Sidoarjo memiliki 18 kecamatan yang terbagi menjadi 350 desa dengan jumlah penduduk sekitar 2.3 juta jiwa (DLHK Kabupaten Sidoarjo, 2017). Kegiatan ekonomi masyarakat kabupaten Sidoarjo termasuk kecamatan Tanggulangin digerakkan oleh sektor industri tas, koper, sepatu, pabrik rokok, perairan darat (tambak), pertanian serta rumah makan (kuliner) (Sutikno, 2010). Kegiatan-kegiatan tersebut menghasilkan limbah padatan sebagai aktivitas yang tanpa akhir. Timbulan sampah di kabupaten Sidoarjo juga berasal dari rumah tangga dari sekitar 2.3 juta jiwa penduduknya. Sementara itu, masyarakat masih memiliki kebiasaan yang buruk, kepedulian yang rendah serta pengetahuan yang kurang terkait dengan sampah yaitu kebiasaan membuang sampah tanpa pemilahan, kebiasaan membuang sampah di lahan lahan kosong tanpa pengolahan apapun, kebiasaan membuang sampah di sungai, kurangnya pengetahuan tentang pengelolaan sampah yang efektif, serta kurangnya pengetahuan tentang dampak sumbatan sungai dan dampak rusaknya lingkungan bagi kehidupan sekarang dan masa mendatang. Timbulan sampah banyak terkumpul di lahan kosong, di jalan jalan desa serta sungai. Hal tersebut mengakibatkan munculnya pemandangan yang tidak sedap dipandang, bau yang menyengat serta pendangkalan sungai. Dampak lanjutan dari kondisi tersebut adalah terjadinya bencana banjir yang terjadi setiap musim penghujan, berkurangnya ketersediaan air bersih, berkurangnya pasokan air untuk irigasi sawah serta munculnya berbagai macam penyakit pada masyarakat. Masalah persampahan di daerah perkotaan juga terjadi karena adanya kesulitan dalam hal pemilahan sampah dan upaya mendapatkan tempat atau lahan yang benar benar aman yang dapat digunakan sebagai tempat pembuangan sampah
(Soeryani et al, 1997). Dampak negatif keberadaan Tempat Pembuangan Akhir Sampah (TPAS) adalah terjadi penurunan tingkat kesehatan dan penurunan kualitas lingkungan sekitar (Rangkuti, 2014).

Menjawab salah satu pilar Pembangunan Berkelanjutan yang telah ditetapkan oleh Kementrian PPN/ Bappenas yaitu pilar pembangunan lingkungan yang memiliki 6 tujuan pembangunan berkelanjutan antara lain penyediaan air bersih dan sanitasi layak, pembangunan kota dan pemukiman yang berkelanjutan, penyediaan konsumsi dan produksi yang bertanggung jawab, penanganan perubahan iklim, penyelamatan ekosistem lautan dan penyelamatan ekosistem daratan, maka pihak akademisi dari perguruan tinggi sangat diharapkan berkontribusi untuk ikut serta dalam pembangunan lingkungan tersebut. Peran perguruan tinggi terkait dengan penyelamatan ekosistem daratan salah satunya adalah melakukan transfer ilmu pengetahuan dan mengkampanyekan kepada masyarakat tentang pengelolaan sampah yang efektif dan benar yang dapat dilakukan oleh masyarakat atau yang dikenal dengan Pengelolaan Sampah Berbasis Masyarakat (PSBM). PSBM ini dianggap efektif menurut penelitian Faizah, 2008 dalam mereduksi timbulan sampah dengan melakukan $3 \mathrm{R}$ (Reduce, Reuse dan Recycle) yang dilanjutkan dengan kegiatan komposting sampah organik rumah tangga menjadi kompos. Selain dapat menurunkan volume timbulan sampah di lingkungan dan di TPAS, PSBM dengan komposting skala rumah tangga akan menghasilkan kompos yang dapat digunakan untuk menyuburkan lahan dan tanaman budidaya masyarakat yang bersifat ramah lingkungan. Produksi kompos skala rumah tangga pada akhirnya juga dapat menjadi alternatif usaha industri yang menghasilkan keuntungan ekonomi.

Kompos merupakan bahan organik, seperti daun-daunan, jerami, alang-alang, rumput-rumputan, dedak padi, batang jagung, sulur, carang-carang serta kotoran hewan yang telah mengalami proses dekomposisi oleh mikroorganisme pengurai, sehingga dapat dimanfaatkan untuk memperbaiki sifatsifat tanah. Kompos mengandung hara-hara mineral yang esensial bagi tanaman (Widarti dkk, 2015). Komposting adalah proses pembuatan kompos, yang terjadi baik secara alami maupun buatan. Oleh karena aktivitas pembuangan sampah merupakan aktiitas yang tanpa akhir ditambah pula terdapat 
kesulitan mendapatkan lahan yang benar benar aman sebagai tempat pembuangan sampah di perkotaan, maka PSBM komposting skala rumah tangga dapat menjadi metode untuk pengelolaan sampah di kabupaten Sidoarjo.

Tujuan pelaksanaan Pengabdian Masyarakat ini adalah memberikan penyuluhan tentang sampah dan bahayanya dan melaksanakan pelatihan komposting dari bahan bahan organik sampah rumah tangga.

\section{METODE}

Metode pelaksanaan yang dilaksanakan dalam program pengabdian masyarakat ini adalah melakukan penyuluhan atau kampanye kepada masyarakat Desa Ketegan Kecamatan Tanggulangin Sidoarjo tentang bahaya sampah. Kampanye dilanjutkan dengan pelatihan pemilahan sampah dan komposting sampah dengan menggunakan bahan baku dan alat sederhana yang mudah didapatkan sebagai kegiatan Pengelolaan Sampah Berbasis Masyarakat. Masyarakat akan melakukan praktek pembuatan kompos secara langsung yang dipandu oleh tim pengabdi. Pada saat pelatihan, peserta diminta membawa sampah sayur sayuran hijau, buah buahan sisa yang merupakan limbah dapur rumah tangga masing masing.

Kampanye atau penyuluhan akan dilaksnakan oleh tim pengabdi dengan pokok bahasan antara lain pengertian sampah, jenis jenis sampah, bahaya sampah bagi lingkungan dan kesehatan, permasalahan perkotaan terkait dengan kesulitan pencarian lahan yang benar-benar aman digunakan sebagai Tempat Pembuangan Sampah, peran aktif masyarakat dalam pengelolaan sampah (Pengelolaan Sampah Berbasis Masyarakat), komposting serta nilai ekonomi kompos sebagai alternatif usaha.

Pelatihan komposting dilakukan dengan menggunakan bahan baku berupa sampah organik yang berasal dari dapur rumah tangga dan sampah organik kebun. Pengadaan alat komposting dan bahan aktivator EM4 dan molase disediakan oleh tim pengabdi. Metode yang dilakukan menyadur dari hasil penelitian yang telah dilakukan Subandriyo, 2012 yaitu fermentasi dilakukan secara aerob dengan menggunakan campuran EM4/MOL sebesar 0.6 sampai dengan 1.2 dengan waktu fermentasi 14 sampai dengan 30 hari.

\section{HASIL DAN PEMBAHASAN}

Hasil diskusi dan survei yang dilakukan dengan kepala desa Ketegan ataupun pengamatan secara langsung kondisi lingkungan menunjukkan banyaknya sampah yang bertumpuk di tepi jalan persawahan dan sungai sungai yang melintasi desa. Sampah yang bertumpuk bercampur aduk antara sampah organik dan sampah anorganik sehingga menimbulkan pemandangan yang buruk, mengundang lalat dan serangga lain serta bau yang tidak sedap. Sehingga program pengabdian masyarakat berupa kampanye untuk mengubah perilaku masyarakat harus dilaksanakan serta pelatihan komposting skala rumah tangga juga diperlukan untuk mengurangi volume sampah.

Hasil diskusi dengan kepala Desa Ketegan mendapatkan beberapa informasi antara lain di desa Ketegan tidak terdapat Tempat Pembuangan Sampah yang sesungguhnya sehingga masyarakat cenderung membuang sampah di tepi jalan persawahan atau membakar sampah. Masyarakat belum pernah mendapatkan info cara mengolah sampah dan belum pernah mendapatkan ajakan atau kampanye untuk turut serta menjaga lingkungan hidup sehingga hal tersebut menjadikan tingkat kesadaran masyarakat yang masih rendah akan bahaya dan dampak buruk yang dapat ditimbulkan dari sampah yang menumpuk. Kepala Desa Ketegan juga menjelaskan bahwa di desanya terdapat beberapa greenhouse desa yang telah dibangun dari program pemerintah, akan tetapi kondisi greenhouse tersebut terbengkalai dan tidak terurus. Kepala Desa berharap jika masyarakat telah mendapat kampanye lingkungan dan mampu membuat kompos sendiri dari hasil limbah organik dapur rumah tangganya, maka volume sampah menjadi berkurang, lingkungan menjadi bersih dan nyaman serta masyarakat dapat memanfaatkan greenhouse untuk menanam tanaman dengan kompos buatan sendiri sebagai pupuknya. Sasaran masyarakat yang diundang dalam kegiatan kampanye lingkungan hidup dan pelatihan komposting skala rumah tangga ini berjumlah 24 orang yang terdiri dari ibu-ibu kader penggerak PKK dan karang taruna pemuda dan pemudi. Pelaksanaan kegiatan pengabdian masyarakat disepakati hari Minggu tanggal 5 Agustus 2018 bertempat di Balai Desa Ketegan. 


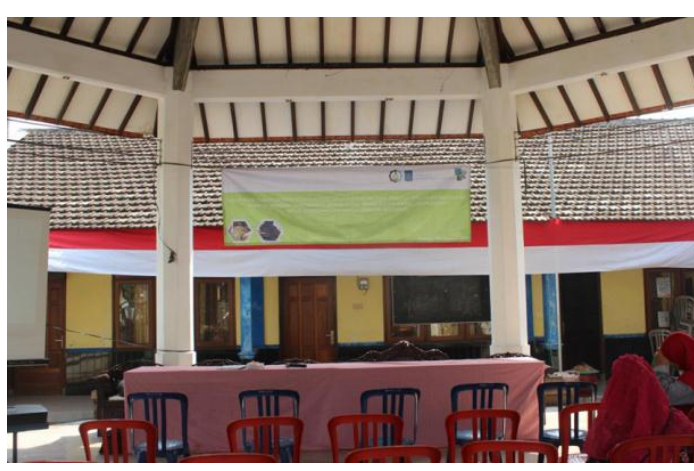

Gambar 1. Persiapan Tempat Pelaksanaan Pengabdian Masyarakat

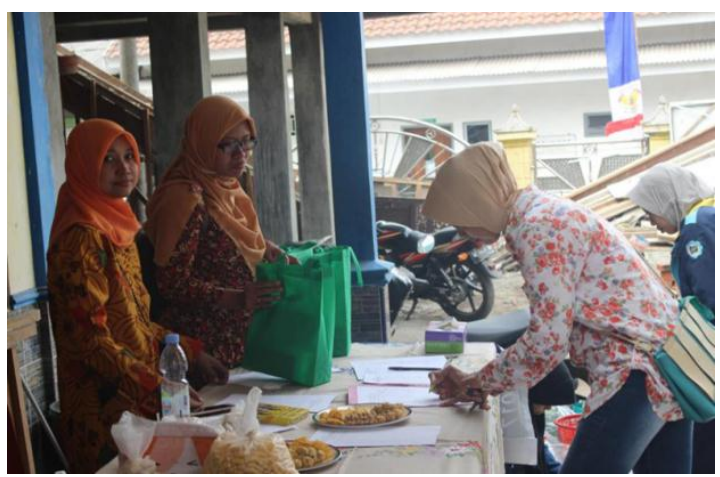

Gambar 2. Registrasi Peserta

Tahap persiapan dengan dosen dan mahasiswa dilaksanakan selama satu bulan yaitu di bulan Juli 2018. Dosen membuat materi kampanye lingkungan hidup dan pelatihan komposting sedangkan mahasiswa yang terlibat melakukan persiapan teknis antara lain membuat surat undangan, pembuatan spanduk pelatihan, peminjaman alat, sewa kendaraan untuk transportasi serta pembelian alat dan bahan untuk komposting. Tahap pelaksanaan program pengabdian masyarakat berupa kampanye dan pelatihan komposting dilaksanakan pada hari Minggu tanggal 5 Agustus 2018 bertempat di Balai Desa Ketegan Tanggulangin. Materi kampanye dan pelatihan disampaikan oleh dosen dan dibantu oleh mahasiswa.

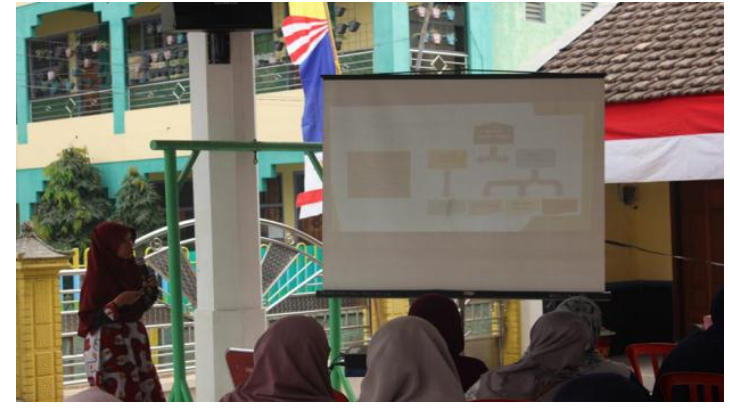

Gambar 3. Penyampaian Materi Kampanye dan Pelatihan Komposting

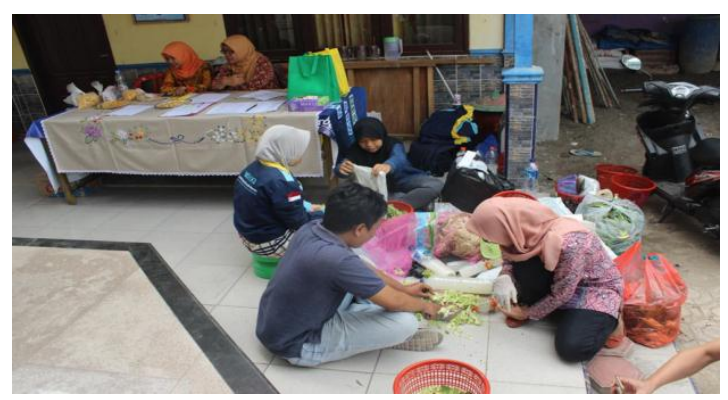

Gambar 4. Persiapan Pencacahan sampah dapur yang telah dikumpulkan peserta

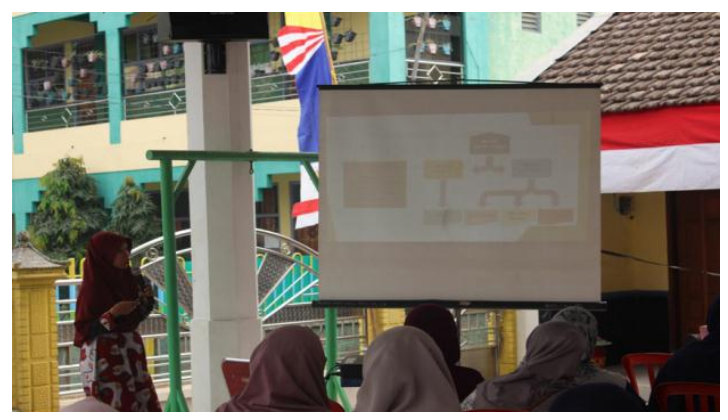

Gambar 5. Pelaksanaan pelatihan komposting

Pada akhir pelaksanaan pelatihan, peserta diminta untuk mengisi kuisioner dan umpan balik. Kuisioner diperlukan untuk mengetahui respon peserta terhadap program pengabdian masyarakat. Sedangkan umpan balik digunakan untuk mengukur keberhasilan penyampaian materi yang telah diberikan yang mampu diserap oleh peserta. 


\section{SIMPULAN DAN SARAN}

Kesimpulan program pengabdian masyarakat berupa kampanye dan pelatihan komposting mendapat apresiasi yang baik dari perangkat desa dan masyarakat peserta. Peserta cukup berminat untuk mempraktekkan di rumah masing masing proses pembuatan komposting. Saran dalam penyuluhan dan pelatihan composting ini adalah peserta menginginkan adanya monitoring oleh tim pengabdi terhadap hasil komposting yang telah dilakukan masing masing peserta.

\section{DAFTAR PUSTAKA}

Azwar, A., 1990. Pengantar IImu Kesehatan Lingkungan . Jakarta.Mutiara Sumber Widya

Depkes, RI. 1987. Pedoman Bidang Studi Pembuangan Sampah . Akademi Penilik Kesehatan Teknologi Sanitasi (APKTS). Jakarta .Proyek Pengembangan Pendidikan Tenaga Sanitasi Pusat Departemen Kesehatan

Faizah, 2008. Pengelolaan Sampah Rumah Tangga Berbasis Masyarakat (Studi Kasus di Kota Yogyakarta). Tesis Magister Ilmu Lingkungan. Universitas Diponegoro. Semarang.

Rangkuti, F.A., 2014. Dampak Keberadaan Tempat Pembuangan Akhir Sampah "Namo Bintang" Terhadap Masyarakat (Studi Kasus: Desa Namo Bintang, Kecamatan Pancur Batu, Kabupaten Deli Serdang). Skripsi. IPB. Bogor

Subandriyo., Anggoro, D.D., Hadiyanto, 2012. Optimasi Pengomposan Sampah Organik Rumah Tangga Menggunakan Kombinasi Aktivator EM4 dan MOL Terhadap Rasio C/N. Jurnal Ilmu Lingkungan. 10(2). 70-75 pp

Sutikno, 2010. Analisis Perubahan Kinerja dan Struktur Ekonomi Kabupaten Sidoarjo Sebelum dan Saat Terjadinya Semburan Lumpur Lapindo. Jurnal Ekonomi Pembangunan. 8(2).
Widarti, B.N., Wardhini, W.K., dan Sarwono, E., 2015. Pengaruh Rasio C/N Bahan Baku Pada Pembuatan Kompos dari Kubis dan Kulit Pisang. Jurnal Integrasi Proses. 5(2). 75-80 pp 